\title{
Soil moisture modifies the response of soil respiration to temperature in a desert shrub ecosystem
}

\author{
B. Wang ${ }^{1,2}$, T. S. Zha ${ }^{1}$, X. Jia ${ }^{1}$, B. Wu ${ }^{1}$, Y. Q. Zhang ${ }^{1}$, and S. G. Qin ${ }^{1}$ \\ ${ }^{1}$ Yanchi Research Station, School of Soil Water Conservation, Beijing Forestry University, Beijing 100083, China \\ ${ }^{2}$ Faculty of Science and Forestry, School of Forest Sciences, University of Eastern Finland, Joensuu 80101, Finland \\ Correspondence to: T. S. Zha (tianshanzha@bjfu.edu.cn) and Y. Q. Zhang (zhangyq@bjfu.edu.cn)
}

Received: 6 May 2013 - Published in Biogeosciences Discuss.: 10 June 2013

Revised: 5 December 2013 - Accepted: 11 December 2013 - Published: 22 January 2014

\begin{abstract}
The current understanding of the responses of soil respiration (Rs) to soil temperature (Ts) and soil moisture is limited for desert ecosystems. Soil $\mathrm{CO}_{2}$ efflux from a desert shrub ecosystem was measured continuously with automated chambers in Ningxia, northwest China, from June to October 2012. The diurnal responses of Rs to Ts were affected by soil moisture. The diel variation in Rs was strongly related to Ts at $10 \mathrm{~cm}$ depth under moderate and high volumetric soil water content (VWC), unlike under low VWC. Ts typically lagged Rs by $3-4 \mathrm{~h}$. However, the lag time varied in relation to VWC, showing increased lag times under low VWC. Over the seasonal cycle, daily mean Rs was correlated positively with Ts, if VWC was higher than $0.08 \mathrm{~m}^{3} \mathrm{~m}^{-3}$. Under lower VWC, it became decoupled from Ts. The annual temperature sensitivity of Rs $\left(Q_{10}\right)$ was 1.5 . The short-term sensitivity of Rs to Ts varied significantly over the seasonal cycle, and correlated negatively with Ts and positively with VWC. Our results highlight the biological causes of diel hysteresis between Rs and Ts, and that the response of Rs to soil moisture may result in negative feedback to climate warming in desert ecosystems. Thus, global carbon cycle models should account the interactive effects of Ts and VWC on Rs in desert ecosystems.
\end{abstract}

\section{Introduction}

Soil respiration (Rs) is receiving widespread attention as a key component of the global C cycle (Schimel, 1995). Rs accounts for $60-90 \%$ of total ecosystem respiration (Raich et al., 2002; Schimel et al., 2001) and its global integral is an order of magnitude larger than anthropogenic $\mathrm{CO}_{2}$ re- leases from burning fossil fuels and land-use change (Marlan et al., 2008). Soil $\mathrm{CO}_{2}$ efflux measurements are contributing to our knowledge and understanding of Rs in many ecosystems. However, Rs is not yet well documented for semiarid and desert ecosystems, due in part to their low productivity which has caused them to be overlooked (Chen and Tian, 2005). Drylands cover a quarter of the earth's land surface (Reynolds, 2001) and are rapidly expanding due to human population growth and global climate change (Geist and Lambin, 2004). Carbon-cycle measurements from arid and semi-arid ecosystems are thus critical to ensure the accurate representation of these ecosystems in large-scale carbon models. Carbon cycling in deserts may be particularly vulnerable to climate and land-use changes (Feng et al., 2001; Wang et al., 2004). The carbon dynamics of desert ecosystems and their response to environmental factors are critical knowledge gaps in the global carbon budget (Cable et al., 2011). In addition to soil temperature (Ts), also volumetric soil water content (VWC) is of primary importance for predicting the evolution of soil carbon stock and fluxes. This is because it strongly controls the decomposition of soil organic matter (Jassal et al., 2008; Liu et al., 2009; Moyano et al., 2012), root respiration (Palta and Nobel, 1989; Bouma et al., 1997), and microbial activity (Linn and Doran, 1984; Skopp et al., 1990; Hallett and Yong, 1999; Drenovsky et al., 2004). VWC is predicted to change at the global scale in the following decades related to global climate change (Wetherald and Manabe, 2002).

Global climate change is predicted to be associated with an increase of temperature and precipitation variability, which may potentially also exacerbate aridity in some desert ecosystems (Lioubimtseva and Henebry, 2009). 
The associated impacts on the hydrological cycle of desert ecosystems include shorter wet periods and longer intervals of periodic drought. During the dry and warm portions of the year in desert ecosystems, VWC may have a greater influence than temperature on Rs (Conant et al., 2004). Although Ts is the major control of Rs through its influence on the kinetics of microbial decomposition, root respiration and the diffusion of enzymes and substrates (Jassal et al., 2008), low VWC limits microbial respiration by restricting access to $\mathrm{C}$ substrates, reducing the diffusion of $\mathrm{C}$ substrates and extracellular enzymes, and limiting microbial mobility (Yuste et al., 2003). The temporal variation in Rs for desert ecosystems, and its response to Ts and VWC, are expected to differ from other ecosystems due to differences in the variation of environmental conditions. In desert ecosystem, however, the seasonal dependence of Rs on both Ts and VWC is still poorly understood (Raich, 2002).

The sensitivity of Rs to Ts is often described by the $Q_{10}$ model, where $Q_{10}$ is the factor by which Rs increases for a $10^{\circ} \mathrm{C}$ increment in temperature (Van't Hoff, 1898). $Q_{10}$ is reduced by low substrate availability, low VWC and high Ts (Geist, 2004), all of which are characteristic of desert ecosystems. However, desert ecosystems are also characterized by temporal extremes in Ts and VWC, and little is known about the related temporal variation in $Q_{10}$ or its response to environmental factors.

Rs is usually highly correlated with Ts (Jassal et al., 2005). However, some studies have reported significant hysteresis in the seasonal cycles of Rs and Ts (Xu and Qi, 2001; Parkin and Kaspar, 2003; Subke et al., 2003; Jia et al., 2013), and shown a decoupling of Rs from Ts during drought. In some studies, low VWC has been suggested to increase the degree of hysteresis between Rs and Ts (Tang et al., 2005; Vargas and Allen, 2008; Carbone et al., 2008; Phillips et al., 2011), but opposite results have also been reported (RiverosIregui et al., 2007). Both biological and physical explanations have been suggested for the hysteresis patterns (Phillips et al., 2011). However, no consensus has been reached so far. Phillips et al. (2011) and Riveros-Iregui et al. (2007) have demonstrated for forest ecosystems that the diel phase lags between Rs and Ts may result from differences in the heat and $\mathrm{CO}_{2}$ transport processes. However, in desert ecosystems with sandy soils, the low VWC and high soil porosity may maximize these lags. The magnitude and the causes of hysteresis and its variation are still unclear for desert ecosystems.

Therefore, we hypothesized: (1) desert soil respiration is highly limited by soil moisture and less sensitive to Ts; and (2) the soil moisture in desert ecosystems affects Rs responses to Ts not only seasonally, but also diurnally. This study reports continuous Rs measurements from a desert shrubland ecosystem in northwest China. The objectives were (1) to quantify the temporal variations of Rs and its impact factors; (2) to understand the influence of VWC on the sensitivity of Rs to Ts; and (3) to explore the effects of VWC on hysteresis in the Rs-Ts relationship over the seasonal cycle.

\section{Materials and methods}

\subsection{Site description}

The research was conducted on a sand dune at the Yanchi Research Station $\left(106^{\circ} 30^{\prime}\right.$ to $107^{\circ} 41^{\prime} \mathrm{E}$ and $37^{\circ} 04^{\prime}$ to $\left.38^{\circ} 10^{\prime} \mathrm{N}\right)$ of Beijing Forestry University, Ningxia, northwest China. The site is located at the edge of the Mu Us Desert in the transition between arid and semi-arid climatic zones, at an elevation of $1550 \mathrm{~m}$ a.s.l. The sandy soil has a bulk density of $1.6 \mathrm{~g} \mathrm{~cm}^{-3}$. The prevailing climate is of the temperature arid and semi-arid type. The mean annual precipitation is $292 \mathrm{~mm}$, of which $62 \%$ falls between July to September. The mean annual total of potential evapotranspiration is $2024 \mathrm{~mm}$. The mean annual temperature is $8.1^{\circ} \mathrm{C}$. All meteorological data were provided by the meteorological station of Yanchi County and represent 51 yr averages (1954-2004). The vegetation has been recovered for $10 \mathrm{yr}$. The dominant vegetation is Artemisia ordosical, with sparse Hedysarum mongolicum.

\subsection{Soil respiration measurements}

Continuous measurements of Rs were made in situ using an automated soil respiration system (model LI-8100A fitted with a LI-8150 multiplexer, LI-COR, Nebraska, USA). Measurements were made on a typically sized fixed sand dune, along two $26 \mathrm{~m}$ line transects that originated at the center of the dune. Eleven permanent PVC collars were installed on average at $3 \mathrm{~m}$ spacing in March 2012, three months before the first Rs measurements. The collars were $20.3 \mathrm{~cm}$ in diameter and $10 \mathrm{~cm}$ in height, with $7 \mathrm{~cm}$ inserted into the soil. The collar locations represented four positions (top, upper-slope, lower-slope, and inter-hill) and four aspects (north-face, south-face, windward and leeward) along the dune slope.

Hourly Rs was continuously measured from June to October 2012. A permanent opaque chamber (model LI-104, LI-COR, Nebraska, USA) was set on each collar. The measurement time for each chamber was $3 \mathrm{~min}$ and $15 \mathrm{~s}$, including a $30 \mathrm{~s}$ pre-purge, a $45 \mathrm{~s}$ post-purge, and a $2 \mathrm{~min}$ observation period. Any plant re-growth within the measurement collar was manually removed. Hourly Ts and VWC at $10 \mathrm{~cm}$ depth were measured outside of each chamber using the 8150-203 soil temperature sensor and $\mathrm{EC}_{\mathrm{H}_{2} \mathrm{O}}$ soil moisture sensor (LI-COR, Nebraska, USA), respectively. Rainfall was measured about $1 \mathrm{~km}$ away, using a manual rain gauge before 22 July 2012, and a tipping-bucket rain gauge (model TE525MM, Campbell Scientific, UT, USA) after 22 July 2012. 


\subsection{Data processing and analysis}

The Rs data were screened using limit checking. Hourly $\mathrm{CO}_{2}$ effluxes out from the range of -1 to $15 \mu \mathrm{mol} \mathrm{CO} \mathrm{Cm}^{-2} \mathrm{~s}^{-1}$ were considered abnormal and removed from the data set. Instrument failure and quality control procedures resulted in $3 \%$ missing data from 4 June to 22 October 2012. Hourly means were computed as the mean of the 11 chambers, and daily means were computed as the average of the hourly means. The mean diel cycles of Rs and Ts were computed for each month by averaging the hourly means for each time of day; the cycles were then used to analyze the diel variation in Rs and identify hysteresis in the Rs-Ts relationship. For a better understanding of the diel variation in Rs in response to Ts and VWC, we selected three-day periods with contrasting VWC. Daily mean values were used to examine the seasonal responses of Rs to Ts and VWC. In evaluating the Rs response to Ts, the measurements during rainfall were excluded to minimize the effects of the rain pulse.

Regression analysis was used to evaluate the relationships between Rs and Ts and VWC. Normalized daily mean Rs $\left(\mathrm{Rs}_{\mathrm{N}}\right)$, computed as the ratio of observed Rs to the value predicted by the best-fit Rs-Ts model, was used to analyze the seasonal dependence of Rs on VWC (Fig. 7). Three commonly used models (Table 2), all of which fit the data well, were used to analyze the response of Rs to Ts. Three different bivariate models with Ts and VWC as independent variables were developed to represent the combined effect of both variables (Table 3). Akaike information criterion (AIC) was used to evaluate the goodness of the Rs models (Posada and Buckley, 2004).

$\mathrm{AIC}=n \times \operatorname{Ln}(\mathrm{SSE})+2 \times(p+1)-n \times \operatorname{Ln}(n)$,

where SSE is the sum of squares for error, $n$ the sample capacity, $p$ the amount of independent variables used in regression analysis.

Seasonal changes in the sensitivity of Rs to Ts at $10 \mathrm{~cm}$ depth $\left(Q_{10}\right)$ were analyzed using short-term $Q_{10}$ derived from fitting the $Q_{10}$ model to synchronized data from a threeday moving window with a one-day step (Fig. 8). Crosscorrelation analysis was used to detect hysteresis between Rs and $\mathrm{Ts}$ at diel timescales, and to synchronize the values before regression analysis was performed. All analyses were processed in Matlab 7.11.0 (R2010b, The Mathworks Inc., Natick, MA, USA).

\section{Results}

\subsection{Hysteresis between soil respiration and soil temperature}

Over the diel cycle, hourly Rs was out of phase with Ts at $10 \mathrm{~cm}$ depth (Fig. 1), as seen in the hysteresis in the RsTs relationship (Figs. 1 and 2). The mean time lag between
Table 1. Analysis of the mean monthly diel cycles of soil respiration (Rs) and soil temperature at $10 \mathrm{~cm}$ depth (Ts), including RsTs correlation coefficients before synchronized and lag times in the Rs versus Ts diel cycles. The Pearson correlation coefficient and $p$ value were given.

\begin{tabular}{lrrrrr}
\hline Time & Jun & Jul & Aug & Sep & Oct \\
\hline Ts-Rs & 0.488 & 0.629 & 0.338 & 0.634 & 0.491 \\
lag time & $4 \mathrm{~h}$ & $3 \mathrm{~h}$ & $4 \mathrm{~h}$ & $3 \mathrm{~h}$ & $3 \mathrm{~h}$ \\
$p$ & 0.016 & 0.010 & 0.106 & 0.001 & 0.015 \\
\hline
\end{tabular}

Rs and Ts was $3 \mathrm{~h}$ during July, September and October, and $4 \mathrm{~h}$ during June and August (Table 1), with Rs peaking earlier than Ts. The time lag between Rs and Ts (Figs. 2 and 3) was negatively and linearly related to VWC (Fig. 3; Lag $(\mathrm{h})=-41 \times \mathrm{VWC}+7.3, R^{2}=0.71$, RMSE $\left.=0.56\right)$. Hysteresis was smaller when VWC was higher (Fig. 2c), and vice versa (Fig. 2a). For all model types, i.e both bivariate models (Ts and VWC) and models with Ts only, the $R^{2}$ values derived from the data set with synchronized Rs and Ts were 12-20\% higher than that without synchronization (Table 3).

\subsection{Diel variation of soil respiration and its response to soil temperature and volumetric soil water content}

Over the daily cycle, minimum and maximum hourly Rs occurred at $\sim$ 06:00 LT (GMT +8) and 13:00 (Fig. 1), respectively, while minimum and maximum Ts at $10 \mathrm{~cm}$ depth occurred at 07:00 and 16:00. The diel variation of Rs was strongly influenced by Ts and VWC, as seen in contrasting 3-day time series (Fig. 2). At low VWC and high Ts (Fig. 2a), maximum Rs occurred at 09:00 coinciding well with the Ts minimum, and then sharply decreased as Ts rose, with a subtle, secondary Rs peak at 16:00. At moderate VWC and high Ts (Fig. 2b), Rs rose in response to rising Ts in the early morning but then plateaued at high Ts during the midday before declining with declining Ts. When VWC was high and Ts was low (Fig. 2c), Rs rose in response to rising Ts, Rs peaked earlier (at 12:00) than Ts and there was no evidence of a midday plateau.

The mean diel cycles of hourly Rs and Ts showed significant positive correlations between Rs and Ts for all other months except August (Table 1). The $Q_{10}$, quadratic and logistic models all fit the mean diel variation data poorly. However, when Rs and Ts data were synchronized to remove the time lag, all three models fit the data well, with the best fit from the $Q_{10}$ model (Fig. 4; $R^{2}=0.89$ in August, $R^{2}>0.95$ for other months). 
Table 2. Regression parameters $(a, b, c)$ from temperature-only models of soil respiration, based on the analysis of daily means. Rs ( $\mu$ mol $\left.\mathrm{CO}_{2} \mathrm{~m}^{-2} \mathrm{~s}^{-1}\right)$, Ts $\left({ }^{\circ} \mathrm{C}\right)$ and VWC $\left(\mathrm{m}^{3} \mathrm{~m}^{-3}\right)$ are soil respiration, soil temperature at $10 \mathrm{~cm}$ depth, and soil volumetric water content at $10 \mathrm{~cm}$ depth, respectively. $R^{2}$ is the coefficient of determination. RMSE is the root mean square error. AIC is Akaike's information criterion.

\begin{tabular}{|c|c|c|c|c|c|c|c|}
\hline \multicolumn{2}{|c|}{$\mathrm{VWC}>0.08 \mathrm{~m}^{3} \mathrm{~m}^{-3}$} & \multirow{2}{*}{$\begin{array}{r}a \\
0.69\end{array}$} & \multirow{2}{*}{$\begin{array}{r}b \\
1.9\end{array}$} & \multirow[t]{2}{*}{$c$} & \multirow{2}{*}{$\begin{array}{r}\text { AIC } \\
-213.62\end{array}$} & \multirow{2}{*}{$\begin{array}{c}R^{2} \\
0.75\end{array}$} & \multirow{2}{*}{$\begin{array}{l}\text { RMSE } \\
0.2376\end{array}$} \\
\hline$Q_{10}$ & $\mathrm{Rs}=a \times b^{(\mathrm{Ts}-10) / 10}$ & & & & & & \\
\hline Quadratic & $\mathrm{Rs}=a \times \mathrm{Ts}^{2}+b \times \mathrm{Ts}+c$ & 0.002 & 0.011 & 0.37 & -215.09 & 0.76 & 0.237 \\
\hline Logistic & $\mathrm{Rs}=a /(1+\exp (b \times(c-\mathrm{Ts})))$ & 3.4 & 0.10 & 23.78 & -215.47 & 0.76 & 0.2362 \\
\hline \multicolumn{8}{|c|}{$\mathrm{VWC}<0.08 \mathrm{~m}^{3} \mathrm{~m}^{-3}$} \\
\hline$Q_{10}$ & $\mathrm{Rs}=a \times b^{(\mathrm{Ts}-10) / 10}$ & 0.51 & 1.73 & & & 0.09 & 0.2533 \\
\hline Quadratic & $\mathrm{Rs}=a \times \mathrm{Ts}^{2}+b \times \mathrm{Ts}+c$ & -0.3 & 1.54 & -18.3 & & 0.14 & 0.2504 \\
\hline Logistic & $\mathrm{Rs}=a /(1+\exp (b \times(c-\mathrm{Ts})))$ & 1.2 & 1.07 & 21.1 & & 0.13 & 0.2515 \\
\hline \multicolumn{8}{|l|}{ Total data } \\
\hline$Q_{10}$ & $\mathrm{Rs}=a \times b^{(\mathrm{Ts}-10) / 10}$ & 0.76 & 1.5 & & -239.28 & 0.36 & 0.3373 \\
\hline Quadratic & $\mathrm{Rs}=a \times \mathrm{Ts}^{2}+b \times \mathrm{Ts}+c$ & -0.001 & 0.1 & 0.01 & -242.44 & 0.37 & 0.3341 \\
\hline Logistic & $\mathrm{Rs}=a /(1+\exp (b \times(c-\mathrm{Ts})))$ & 1.56 & 0.2 & 11.8 & -243.36 & 0.38 & 0.3372 \\
\hline
\end{tabular}

Table 3. Regression parameters $(a, b, c, d)$ from univariate and bivariate models of soil respiration on the basis of synchronized and nonsynchronized hourly values. Rs $\left(\mu \mathrm{mol} \mathrm{CO} \mathrm{m}^{-2} \mathrm{~s}^{-1}\right)$, Ts $\left({ }^{\circ} \mathrm{C}\right)$, and VWC $\left(\mathrm{m}^{3} \mathrm{~m}^{-3}\right)$ are soil respiration, soil temperature at $10 \mathrm{~cm}$ depth, and soil water content at $10 \mathrm{~cm}$ depth, respectively. $R^{2}$ is the coefficient of determination. RMSE is the root mean square error. AIC is Akaike's information criterion.

\begin{tabular}{|c|c|c|c|c|c|c|c|c|}
\hline Sync & & $a$ & $b$ & $c$ & $d$ & AIC & $R^{2}$ & RMSE \\
\hline$Q_{10}$ & $\mathrm{Rs}=a \times b^{(\mathrm{Ts}-10) / 10}$ & 0.76 & 1.5 & & & -3901.6 & 0.41 & 0.40 \\
\hline Quadratic & $\mathrm{Rs}=a \times \mathrm{Ts}^{2}+b \times \mathrm{Ts}+c$ & 0.06 & -0.0004 & 0.07 & & -3979.1 & 0.43 & 0.39 \\
\hline Logistic & $\mathrm{Rs}=a /(1+\exp (b \times(c-\mathrm{Ts})))$ & 1.90 & 0.13 & 15.1 & & -3990.2 & 0.44 & 0.39 \\
\hline$Q_{10}$ power & $\mathrm{Rs}=a \times b^{((\mathrm{Ts}-10) / 10)} \times \mathrm{VWC}^{c}$ & 5.53 & 1.81 & 0.90 & & -5992.2 & 0.78 & 0.25 \\
\hline Logistic power & $\mathrm{Rs}=a /(1+\exp (b \times(c-\mathrm{Ts}))) \times \mathrm{VWC}^{d}$ & 24.9 & 0.10 & 23.9 & 0.89 & -6122.7 & 0.80 & 0.23 \\
\hline$Q_{10}$ hyperbolic & $\mathrm{Rs}=a^{((\mathrm{Ts}-10) / 10)} \times(b+c \times \mathrm{VWC}+d / \mathrm{VWC})$ & 1.80 & 0.14 & 5.88 & -0.003 & -5990.5 & 0.78 & 0.24 \\
\hline \multicolumn{9}{|l|}{ Not sync } \\
\hline$Q_{10}$ & $\mathrm{Rs}=a \times b^{(\mathrm{Ts}-10) / 10}$ & 0.80 & 1.44 & & & & 0.29 & 0.4204 \\
\hline Quadratic & $\mathrm{Rs}=a \times \mathrm{Ts}^{2}+b \times \mathrm{Ts}+c$ & -0.001 & 0.07 & 0.08 & & & 0.31 & 0.4129 \\
\hline Logistic & $\mathrm{Rs}=a /(1+\exp (b \times(c-\mathrm{Ts})))$ & 1.62 & 0.14 & 12.1 & & & 0.32 & 0.4117 \\
\hline$Q_{10}$ power & $\mathrm{Rs}=a \times b^{((\mathrm{Ts}-10) / 10)} \times \mathrm{VWC}^{c}$ & 4.9 & 1.67 & 0.81 & & & 0.58 & 0.3216 \\
\hline Logistic power & $\mathrm{Rs}=a /(1+\exp (b \times(c-\mathrm{Ts}))) \times \mathrm{VWC}^{d}$ & 15.1 & 0.12 & 18.3 & 0.798 & & 0.61 & 0.3122 \\
\hline$Q_{10}$ hyperbolic & $\mathrm{Rs}=a^{((\mathrm{Ts}-10) / 10)} \times(b+c \times \mathrm{VWC}+d / \mathrm{VWC})$ & 1.67 & 0.16 & 6.06 & -0.001 & & 0.58 & 0.3218 \\
\hline
\end{tabular}

\subsection{Seasonal variation in soil respiration and its response to soil temperature and volumetric soil water content}

Daily mean Ts was high during June to August $\left(20\right.$ to $\left.25^{\circ} \mathrm{C}\right)$, but gradually declined during September to a mean of $10^{\circ} \mathrm{C}$ in October (Fig. 5a). Daily mean VWC ranged from 0.046 to $0.170 \mathrm{~m}^{3} \mathrm{~m}^{-3}$, with higher values following periods of precipitation, and lower values at the end of drought (Fig. 5). The seasonal variations in VWC and Ts reflected typical desert climatic conditions, with a series of short wet periods followed by longer intervals of drought, and large differences in temperature between day and night (Fig. 5a). Daily mean
Rs showed strong seasonality, peaking in July and declining in autumn, similar to the Ts seasonal cycle but tempered by the VWC seasonal cycle (Fig. 5c). Daily Rs was highest $\left(2.56 \mu \mathrm{mol} \mathrm{CO} 2 \mathrm{~m}^{-2} \mathrm{~s}^{-1}\right)$ on 29 July when VWC and Ts were high, and lowest $\left(0.23 \mu \mathrm{mol} \mathrm{CO} \mathrm{Cm}^{-2} \mathrm{~s}^{-1}\right)$ on 22 October when Ts was low (Fig. 5b). In general, Rs pulses followed precipitation events (Fig. $5 b, c)$.

Over the whole measurement period, daily mean Rs was significantly and positively $(p<0.01)$ related to Ts when VWC was greater than $0.08 \mathrm{~m}^{3} \mathrm{~m}^{-3}$ (Fig. 6, closed circles). The logistic and quadratic models gave the lowest AIC and RMSE, and the highest $R^{2}$ (Fig. 6; Table 2); Ts explained $76 \%$ of the seasonal variation in daily Rs. In contrast, Rs 

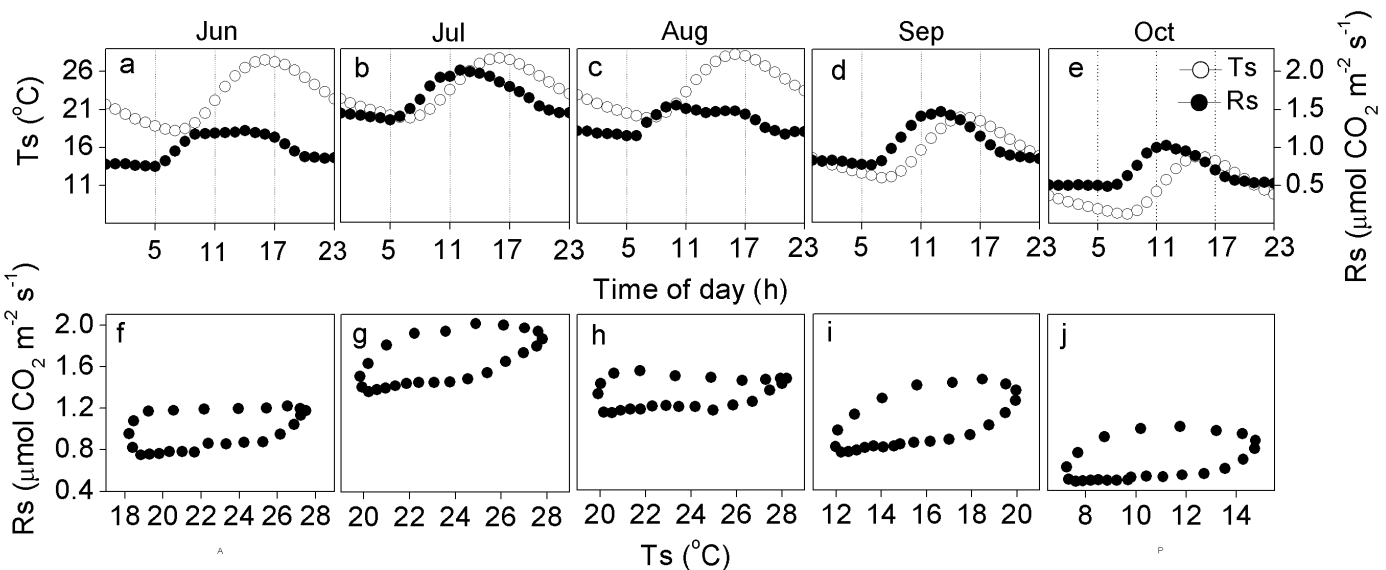

Fig. 1. Mean monthly diel cycles of soil respiration (Rs) and soil temperature (Ts). Each point is the monthly mean for a particular time of day.

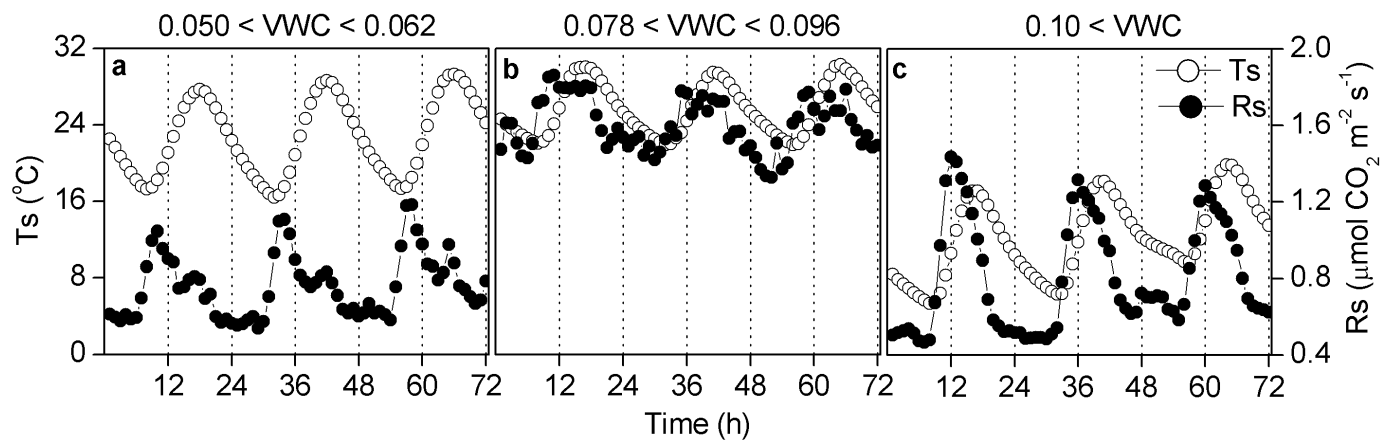

Fig. 2. Hourly soil respiration (Rs) and soil temperature (Ts) over three continuous days under low $\left(0.05-0.06 \mathrm{~m}^{3} \mathrm{~m}^{-3}\right)$, moderate $(0.08-$ $\left.0.10 \mathrm{~m}^{3} \mathrm{~m}^{-3}\right)$, and high $\left(0.10-0.11 \mathrm{~m}^{3} \mathrm{~m}^{-3}\right)$ volumetric soil water content (VWC) conditions.

became decoupled from Ts when VWC was lower than $0.08 \mathrm{~m}^{3} \mathrm{~m}^{-3}$ (open circle on Fig. 6; Table 2; $r=0.307 ; p=$ 0.69 ). Normalized respiration $\mathrm{Rs}_{\mathrm{N}}$, as derived from the logistic model and excluding days with rainfall, was significantly and positively related to $\mathrm{VWC}$ (Fig. $7 ; \mathrm{Rs}_{\mathrm{N}}=8.94 \times \mathrm{VWC}$ $\left.+0.08, R^{2}=0.78, p<0.01\right)$. Overall, the bivariate models with Ts and VWC as independent variables produced a better fit than the Ts-only models (Table 3). Data synchronization, removing the diel lag between Rs and Ts, improved the performance in terms of AIC, $R^{2}$ and RMSE for all models.

\section{4 $Q_{10}$ and its response to soil temperature and volumetric soil water content}

The annual sensitivity of Rs to Ts (parameter $b$ from the $Q_{10}$ model in Table 3 ) was 1.5 . Short-term $Q_{10}$ estimated from a 3-day moving window showed strong seasonality and ranged from $0.63-10$ (Fig. 8a, $Q_{10}$ during rainfall event has been excluded), being lower in June-August than September-October. Periods with rainfall had elevated $Q_{10}$. After removing the data during rainfall, the $Q_{10}$ was significantly and negatively re- lated to Ts (Fig. 8b; $Q_{10}=-0.42 \times$ Ts $+12.4, R^{2}=0.86$, RMSE $=0.91$ ), but positively related to VWC (Fig. 8c; $Q_{10}=18010 \times \mathrm{VWC}^{3.721}+1.604, R^{2}=0.42$, RMSE $=$ $3.165)$.

\section{Discussion}

\subsection{Diel response of soil respiration to volumetric soil water content}

We found that the diel variation of Rs was constrained by VWC. Opposite to our results, for example, Tang et al. (2005) reported for an oak-grass savanna that the diel variation in Rs was largely controlled by Ts, whereas VWC had no affect the diel Rs cycle, but VWC controlled the Rs seasonal pattern. In general, diel variation of VWC can be small or constant over a day while Rs has an obvious diel variation (Gaumont-Guay et al., 2006). In forest ecosystems with high rainfall and high soil moisture, soil respiration may be less limited by VWC and the effect of VWC to diel Rs may be weak. As a comparison, in desert ecosystems soil water 


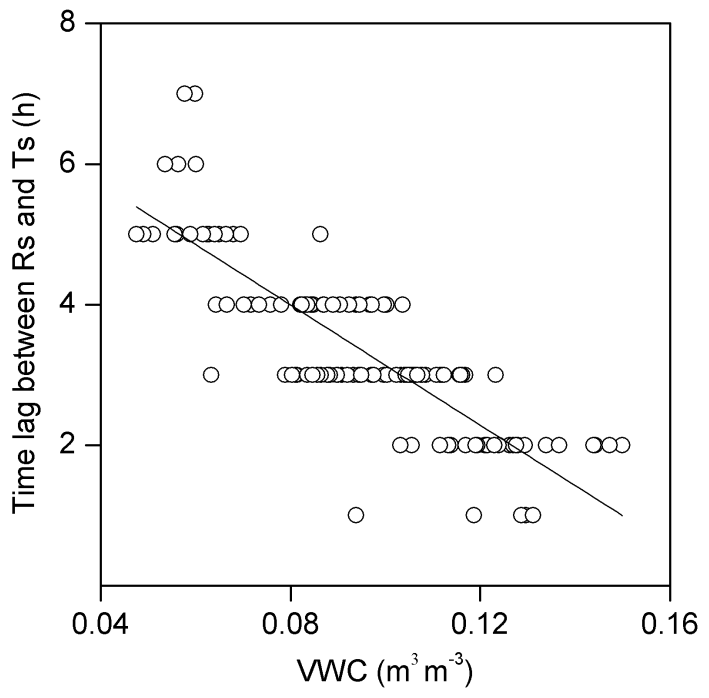

Fig. 3. Lag time between soil respiration (Rs) and soil temperature (Ts) over the diel cycle, in relation to volumetric soil water content (VWC) at $10 \mathrm{~cm}$ soil depth. The lag times were calculated by a cross-correlation analysis using a three-day moving window with one-day step. The solid line is fitted using linear regression.

content is usually low, which makes plants to suffer from water stress and to be very sensitive to VWC; as a result, their leaf stomata may be closed to reduce water loss under high temperature in the midday. This may consequently lead to a reduction in plant photosynthesis and root activity (Chaves et al., 2002). Thus, autotrophic respiration may be constrained or become plateaued, as we did find in our work (Fig. 2b).

However, if soil temperature is in the morning lower than dew-point temperature, condensation water happens on the ground (Agam and Berliner, 2006), increasing root activity and inducing higher root respiration. In fact, we observed that Rs did peak in the morning when temperature was lower and became low in the midday when temperature was higher (Fig. 2a). We also found that when temperature was low and VWC was high, diel variation in Rs corresponded with Ts (Fig. 2c). Rs peaked when Ts was low under low soil water content or when Ts was high under high soil water content. This coincided with the result that hysteresis between Rs and Ts was negatively affected by VWC. In overall, VWC affected strongly the diel response of Rs to Ts in our desert shrub ecosystem.

\subsection{Seasonal soil respiration variation in relation to soil temperature and volumetric soil water content}

The seasonal variation in Rs was controlled primarily by Ts (Fig. 6), with secondary influence by VWC (Fig. 7). Ts explained $76 \%$ of the variation in Rs for $\mathrm{VWC}>0.08 \mathrm{~m}^{3} \mathrm{~m}^{-3}$, but was not correlated with Rs for VWC $<0.08 \mathrm{~m}^{3} \mathrm{~m}^{-3}$ (Table 2). Many previous studies have reported a similar response. For example, Palmroth et al. (2005) found that Rs

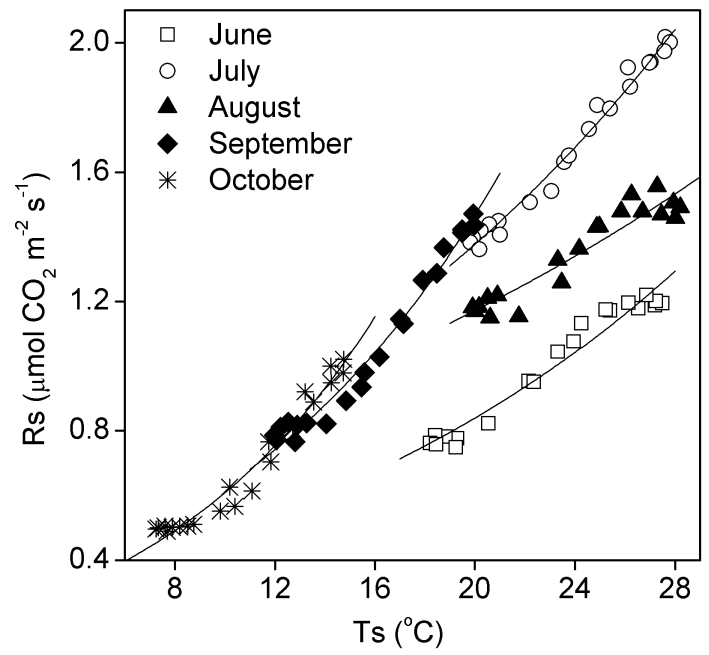

Fig. 4. Mean monthly diel cycles of soil respiration (Rs) and soil temperature (Ts) from Fig. 1, but replotted in relation to each other. The solid line is fitted by the $Q_{10}$ model.

was dependent in a forest ecosystem on both Ts and VWC when the soil was dry (VWC $<0.20 \mathrm{~m}^{3} \mathrm{~m}^{-3}$ ), but depended on Ts alone when the soil was moist (VWC $>0.20 \mathrm{~m}^{3} \mathrm{~m}^{-3}$ ). Jassal et al. (2008) reported for forest ecosystem that Rs became decoupled from Ts when VWC dropped below $0.11 \mathrm{~m}^{3} \mathrm{~m}^{-3}$. The reduction in Rs with decreasing VWC mostly likely resulted from the suppression of plant growth, root and microbial activities, and the decay of soil organic matter at low VWC (Gaumont-Guay et al., 2006; Sotta et al., 2007; Jassal et al., 2008; Liu et al., 2009). Substrate availability and the diffusion of substrates and extracellular enzymes are also reduced when VWC is low (Jassal et al., 2008). Contradictory to some previous studies, our results did not show a distinct VWC threshold above which Rs is decreased. Similar to other desert sites, the reason that the $\mathrm{Rs}_{\mathrm{N}}-\mathrm{VWC}$ relationship does not show a threshold value is that in our experimental site low VWC $\left(0.04-0.16 \mathrm{~m}^{3} \mathrm{~m}^{-3}\right)$ and high soil porosity did not restrict $\mathrm{CO}_{2}$ transport out of soil and $\mathrm{CO}_{2}$ production due to a lack of $\mathrm{O}_{2}$.

The result that bivariate Rs models, with Ts and VWC as independent variables, outperformed models with Ts only (Table 3) highlights the need to include soil moisture effects on Rs for desert ecosystems in global carbon cycle models. Among bivariate models, the logistic-power model performed best, with higher $R^{2}$ and lower RMSE and AIC. This result is similar to that found for a temperate forest stand ( $\mathrm{Yu}$ et al., 2011). Thus, we recommend to use the logistic-power model with VWC and Ts as independent variables for the estimation of soil respiration.

\subsection{The response of $Q_{10}$ to volumetric water content}

The overall $Q_{10}$ of 1.5 for the desert shrub ecosystem is, in our study, at the lower end of the range of 1.25-1.63 

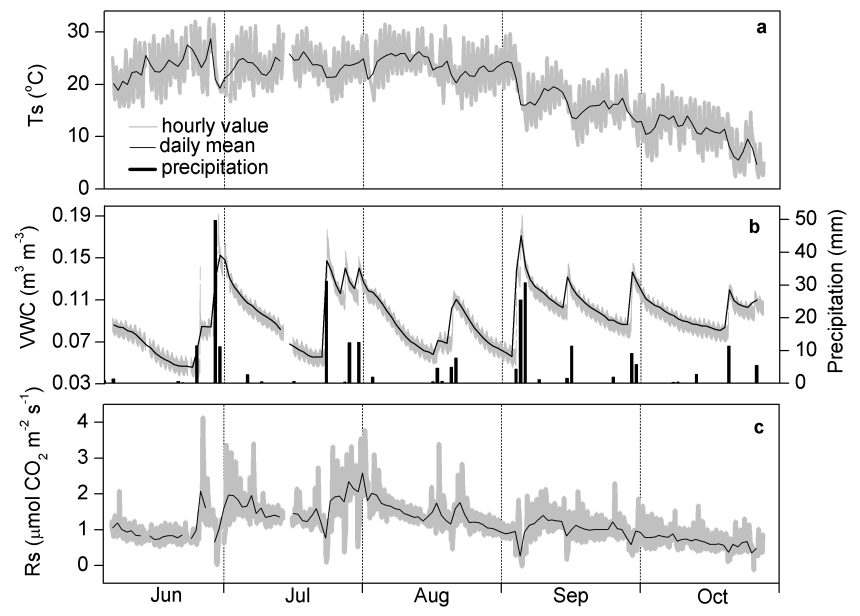

Fig. 5. Seasonal cycles of soil temperature (Ts), volumetric soil water content (VWC), precipitation, and soil respiration (Rs). Ts and VWC were measured at $10 \mathrm{~cm}$ depth. Hourly values are plotted in light grey; the solid line is the daily mean. The precipitation bar plot shows the daily totals.

observed for moss-dominated biological soil crusts to lichendominated biological soil crusts (He, 2012), and of the range of $1.28-4.75$ for spanning alpine, temperate, and tropical ecosystems across China (Zheng et al., 2009). In a global synthesis by Zhou et al. (2009), it was reported for the diverse biomes a range of 1.43-2.03 for $Q_{10}$, with the desert having the lowest $Q_{10}$ values. The low $Q_{10}$ values of desert shrub ecosystems result from their low amount of soil organic matter, small microbial community, and dry soil conditions (Conant et al., 2004; Gershenson et al., 2009; Cable et al., 2011).

The negatively linear relationship observed in our work between $Q_{10}$ and Ts is consistent with the results of many previous studies (e.g., Reichstein et al., 2003; GaumontGuay et al., 2006; Chen et al., 2010; Jia et al., 2013). The $Q_{10}$ dependence on temperature may simply result from the fact that enzymatic processes respond differently over different temperature ranges. Our analyses revealed a limitation in the use of the $Q_{10}$ model that uses a fixed or universal $Q_{10}$ value while temperature vary in a large range. In our mind, the effects of temperature on $Q_{10}$ should not be overlooked. Therefore, a seasonally varying, environmentally controlled $Q_{10}$ should be used for modeling short-term Rs, as was suggested also by Jia et al. (2013).

The positive correlation observed in our study between short-term $Q_{10}$ and VWC over the seasonal cycle (Fig. 8c) is in agreement with previous findings (Chen and Tian, 2005; Gaumont-Guay et al., 2006; Zhang et al., 2010). $Q_{10}$ has been found to decline from 2.5 to 1.0 with increasing drought severity in a Mediterranean evergreen forest ecosystem (Reichstein et al., 2002a). Decreased $Q_{10}$ with decreasing VWC may be due to a switch in the carbon pool of labile substrates to recalcitrant substrates, the carbon pool being respired,

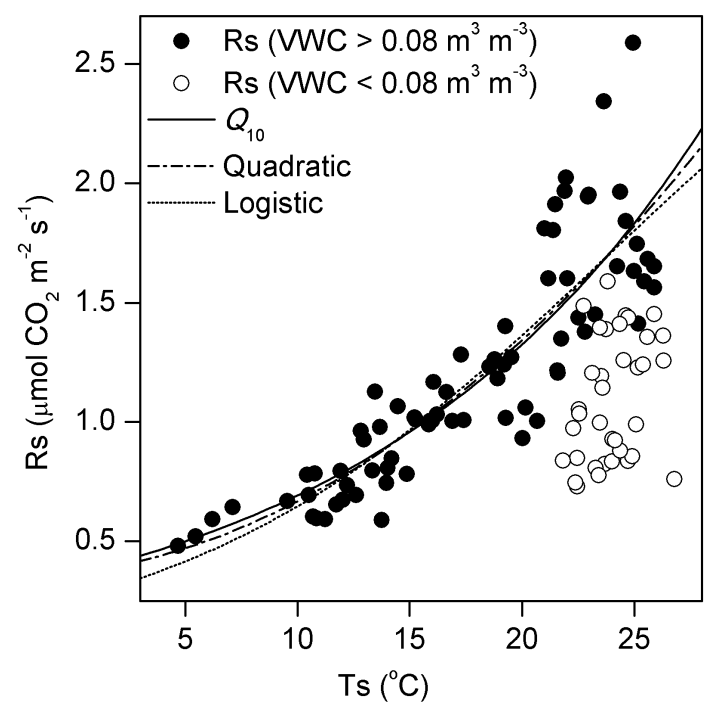

Fig. 6. Relationship between daily mean soil respiration (Rs) and soil temperature (Ts). The lines were fitted using the $Q_{10}$, quadratic, and logistic models.

or to an inactivation of the rhizosphere (Reichstein et al., 2002b). The negative correlation of short-term $Q_{10}$ with Ts and its positive correlation with VWC may result in negative feedbacks by Rs to climate warming by Rs under the increasing temperature and decreasing soil moisture conditions in desert ecosystems.

\subsection{The response of diel hysteresis to volumetric water content}

Our results show a significant lag between Ts at $10 \mathrm{~cm}$ depth and Rs over the diel cycle, and that the lag time increases as VWC decreases. Similar lags between hourly Rs and Ts have been observed also in other ecosystems and they have been found to vary seasonally with soil moisture (Tang et al., 2005; Gaumont-Guay et al., 2006; Riveros-Iregui et al., 2007; Vargas and Allen, 2008). The reason for the lag, however, is unclear. It may be caused by a mismatch between the depth of the Ts measurement and the depth of $\mathrm{CO}_{2}$ production, or by a diurnal variation in the photosynthetic carbon supply which affects the rhizospheric respiration (Parkin and Kaspar, 2003; Subke et al., 2003; Xu and Qi, 201). It may also be attributed to the different responses of autotrophic and heterotrophic respiration to environmental factors (RiverosIregui et al., 2007). Autotrophic respiration responds to photosynthetically active radiation (Liu et al., 2006) and air temperature, whereas heterotrophic respiration responds primarily to soil temperature (Lloyd and Taylor, 1994; Winkler et al., 1996). Our finding that the lag time between Rs and Ts was negatively related to VWC is contrary to the findings of Riveros-Iregui et al. (2007).

Plant photosynthesis has proven to be a factor influencing diel hysteresis between Rs and Ts (Tang et al., 2005). 


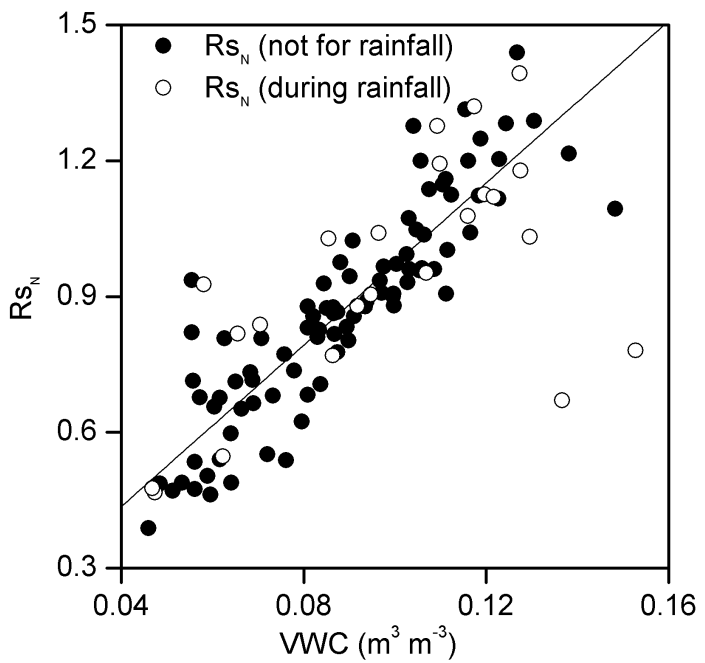

Fig. 7. Relationship between normalized daily mean soil respiration $\left(\mathrm{Rs}_{\mathrm{N}}\right)$ and volumetric soil water content (VWC). $\mathrm{Rs}_{\mathrm{N}}$ is the ratio of the observed soil respiration (Rs) value to the value predicted by the logistic model. The solid line is fitted using linear regression.

Photosynthesis may be an explanation of diel hysteresis under relatively high soil water content, but it does not explain that under lower soil water content. We attribute the increased lag times at low VWC at our experimental site to the decoupling of Rs from Ts when VWC is low, which reflects the sensitivity of root activity to soil water content. The timing of the diurnal Rs peak is highly sensitive to VWC, with progressively earlier peaks as the soil VWC declines. At low VWC, Rs peaks in the early morning because of root activity may strongly increase with condensation water, leading to pronounced hysteresis between Rs and Ts (Fig. 2). In our work, diel hysteresis between Rs and Ts was controlled by both physical and physiology effects. As a result, the variations of the diurnal hysteresis between Rs and Ts are attributed to the biological effects (root activity and plant photosynthesis) in relation to different soil water conditions in desert shrub ecosystems.

\section{Conclusions}

This study reports on findings of continuous soil respiration (Rs) measurements from a desert shrub ecosystem in northwest China, and especially its temporal variation in relation to soil temperature (Ts) and moisture over diel and seasonal cycles. Over the diel cycle, Rs was mainly controlled by Ts, but the response of diel Rs to Ts was adjusted by volumetric soil water content (VWC). There also existed negative correlation between diel hysteresis and VWC. Over the seasonal cycle, the control of Ts over Rs was modified by VWC, Rs became decoupled from Ts when VWC was below $0.08 \mathrm{~m}^{3} \mathrm{~m}^{-3}$. At our experimental site, the logistic-power model (Rs) is a simple but effective model for desert shrub
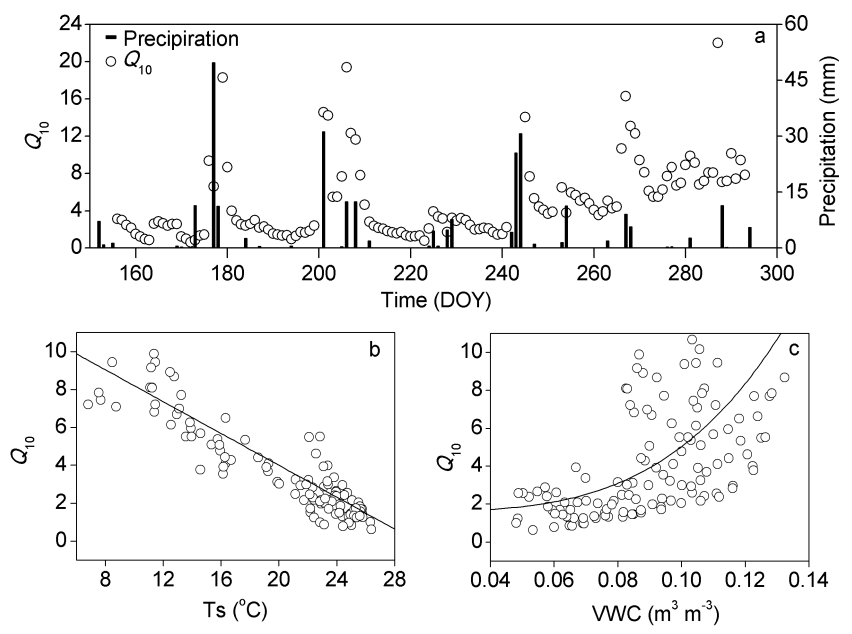

Fig. 8. Short-term $Q_{10}$ as a function of (a) day of year, (b) soil temperature (Ts) and (c) volumetric soil water content (VWC). The $Q_{10}$ values were derived by fitting the $Q_{10}$ model to synchronized data using a three-day moving window with a one-day step. Ts and VWC are three-day means.

ecosystems. The positive correlation between $Q_{10}$ and VWC indicates a potential negative feedback to climate warming, which is often associated with decreasing soil moisture in desert ecosystem. Our results highlight the necessity to account in global carbon cycle models the interactive effects of Ts and VWC on Rs in desert ecosystems.

Acknowledgements. We acknowledge the grants obtained from National Natural Science Foundation of China (NSFC) (proj. no. 31200537, 31270755 and 31361130340) and the Academy of Finland (proj. no. 14921). This research work has been supported especially by the Beijing Forestry University. It is also related to the ongoing Finnish-Chinese research collaboration project EXTREME, between Beijing Forestry University and University of Eastern Finland (UEF), School of Forest Sciences (team led by Heli Peltola). We thank especially Alan Barr for his scientific comments and linguistic revision, and Heli Peltola for her useful suggestions in finalizing phase of the manuscript. Thanks to Huishu Shi, Yuming Zhang, Wei Feng, Sijing Li, Zhihao Chen, Siling Tang, Yajuan Wu and Yuan Li for their assistances with the field measurements and instrumentation maintenance.

Edited by: X. Wang

\section{References}

Agam, N. and Berliner, P. R.: Dew formation and water vapor adsorption in semi-arid environments - a review, J. Arid. Environ., 65, 572-590, 2006.

Bouma, T. J., Nielsen, K. L., Eissenstat, D. M., and Lynch, J. P.: Estimating respiration of roots in soil: interactions with soil $\mathrm{CO}_{2}$, soil temperature and soil water content, Plant. Soil, 195, 221232, 1997. 
Cable, J. M., Ogle, K., Lucas, R. W., Huxman, T. E., Loik, M. E., Smith, S. D., Tissue, D. T., Ewers, B. E., Pendall, E., Welker, J. M., Charlet, T. N., Cleary, M., Griffith, G., Nowak, R. S., Rogers, M., Steltzer, H., Sullivan, P. F., and van Gestel, N. C.: The temperature responses of soil respiration in deserts: a seven desert synthesis, Biogeochemistry, 103, 71-90, 2011.

Carbone, M. S., Winston, G. C., and Trumbore, S. E.: Soil respiration in perennial grass and shrub ecosystems: linking environmental controls with plant and microbial sources on seasonal and diel timescales, J. Geophys. Res., 113, G02022, doi:10.1029/2007JG000611, 2008.

Chaves, M. M., Pereira, J. S., Maroco, J., Rodrigues, M. L., Ricardo, C. P. P., Osório, M. L., Carvalho, I., Faria, T., and Pinheiro, C.: How plants cope with water stress in the field? Photosynthesis and growth, Ann. Bot., 89, 907-916, 2002.

Chen, H. and Tian, H.: Does a general temperature-dependent $Q_{10}$ model of soil respiration exist at biome and global scale?, J. Integr. Plant. Biol., 47, 1288-1302, 2005.

Chen, S., Huang, Y., Zou, J., Shen, Q., Hu, Z., Qi, Y., Chen, H., and Pan, G.: Modeling interannual variability of global soil respiration from climate and soil properties, Agr. Forest. Meteorol., $150,590-605,2010$

Conant, R. T., Dalla-Betta, P., Klopatek, C. C., and Klopatek, J. M.: Controls on soil respiration in semiarid soils, Soil Biol. Biochem., 36, 945-951, 2004.

Drenovsky, R. E., Vo, D., Graham, K. J., and Scow, K. M.: Soil water content and organic carbon availability are major determinants of soil microbial community composition, Microbial. Ecol., 48, 424-430, 2004.

Feng, Q., Cheng, G., and Masao, M.: The carbon cycle of sandy lands in china and its global significance, Climatic Change, 48, 535-549, 2001.

Gaumont-Guay, D., Andrew Black, T. A., Griffis, T. J., Barr, A. G., Jassal, R. S., and Nesic, Z.: Interpreting the dependence of soil respiration on soil temperature and water content in a boreal aspen stand, Agr. Forest. Meteorol., 140, 220-235, 2006.

Geist, H. J. and Lambin, E. F.: Dynamic causal patterns of desertification, Bioscience, 54, 817-829, 2004.

Gershenson, A., Bader, N. E., and Cheng, W.: Effects of substrate availability on the temperature sensitivity if soil organic matter decomposition, Glob. Change Biol., 15, 176-183, 2009.

Hallett, P. D. and Young, I. M.: Changes to water repellence of soil aggregates caused by substrate-induced microbial activity, Eur. J. Soil Sci., 50, 35-40, 1999.

He, M. Z.: Biological soil crusts are the main contributor to winter soil respiration in a temperature desert ecosystem of China, Geophysical Research Abstracts, 14, EGU2012-3306, 2012.

Jassal, R. S., Andrew Black, T., Novak, M. D., Morgenstern, K., Nesic, Z., and Gaumont-Guay, D.: Relationship between soil $\mathrm{CO}_{2}$ concentrations and forest-floor $\mathrm{CO}_{2}$ effluxes, Agr. Forest. Meteorol., 130, 176-192, 2005.

Jassal, R. S., Andrew Black, T., Novak, M. D., Gaumont-Guay, D., and Nesic, Z.: Effect of soil water stress on soil respiration and its temperature sensitivity in an 18-year-old temperate Douglasfir stand, Glob. Change Biol., 14, 1305-1318, 2008.

Jia, X., Zha, T., Wu, B., Zhang, Y., Chen, W., Wang, X., Yu, H., and He, G.: Temperature response of soil respiration in a Chinese pine plantation: hysteresis and seasonal vs. diel $Q_{10}$, Plos One, 8, e57858, doi:10.1371/journal.pone.0057858, 2013.
Linn, D. M. and Doran, J. W.: Effect of water-filled pore space on carbon dioxide and nitrous oxide production in tilled and nontilled soils, Soil Sci. Soc. Am. J., 48, 1267-1272, 1984.

Lioubimtseva, E. and Henebry, G. M.: Climate and environmental change in arid Central Asia: impacts, vulnerability, and adaptations, J. Arid. Environ., 73, 963-977, 2009.

Liu, Q., Edwards, N. T., Post, W. M., Gu, L., Ledford, J., and Lenhart, S.: Temperature independent diel variation in soil respiration observed from a temperate deciduous forest, Glob. Change Biol., 12, 2136-2145, 2006.

Liu, W., Zhang, Z., and Wan, S.: Predominant role of water in regulating soil and microbial respiration and their responses to climate change in a semiarid grassland, Glob. Change Biol., 15, 184-195, 2009.

Lloyd, J. and Taylor, J. A.: On the temperature dependence of soil respiration, Funct. Ecol., 8, 315-323, 1994.

Marlan, G., Boden, T. A., and Andres, R. J.: Global, regional, and national $\mathrm{CO}_{2}$ emissions, in: Trends: a Compendium of Data on Global Change. Carbon Dioxide Information Analysis Center, Oak Ridge National laboratory, US Department of Energy, Oak Ridge, Tennessee, USA, 2008.

Moyano, F. E., Vasilyeva, N., Bouckaert, L., Cook, F., Craine, J., Curiel Yuste, J., Don, A., Epron, D., Formanek, P., Franzluebbers, A., Ilstedt, U., Kätterer, T., Orchard, V., Reichstein, M., Rey, A., Ruamps, L., Subke, J.-A., Thomsen, I. K., and Chenu, C.: The moisture response of soil heterotrophic respiration: interaction with soil properties, Biogeosciences, 9, 1173-1182, doi:10.5194/bg-9-1173-2012, 2012.

Palmroth, S., Maier, C. A., McCarthy, H. R., Oishi, A. C., Kim, H.-S., Johnsen, K. H., Katul, G. G., and Oren, R.: Contrasting responses to drought of forest floor $\mathrm{CO}_{2}$ efflux in a Loblolly pine plantation and a nearby Oak-Hickory forest, Glob. Change Biol., 11, 421-434, 2005.

Palta, J. A. and Nobel, P. S.: Influence of soil $\mathrm{O}_{2}$ and $\mathrm{CO}_{2}$ on root respiration for Agave deserti, Physiol. Plantarum, 76, 187-192, 1989.

Parkin, T. B. and Kaspar, T. C.: Temperature controls on diurnal carbon dioxide flux: implications for estimating soil carbon loss, Soil Sci. Soc. Am. J., 67, 1763-1772, 2003.

Phillips, C. L., Nickerson, N., Risk, D., and Bond, B. J.: Interpreting diel hysteresis between soil respiration and temperature, Glob. Change Biol., 17, 515-527, 2011.

Posada, D. and Buckley, T. R.: Model selection and model averaging in phylogenetics: advantages of akaike information criterion and bayesian approaches over likelihood ratio tests, Syst. Biol., 53, 793-808, 2004.

Raich, J. W., Potter, C. S., and Bhagawati, D.: Interannual variability in global soil respiration, 1980-94, Glob. Change Biol., 8, 800-812, 2002.

Reichstein, M., Tenhunen, J. D., Roupsard, O., Ourcival, J.-M., Rambal, S., Dore, S., and Valentini, R.: Ecosystem respiration in two Mediterranean evergreen Holm oak forests: drought effects and decomposition dynamics, Funct. Ecol., 16, 27-39, 2002a.

Reichstein, M., Tenhunen, J. D., Roupsard, O., Ourcival, J.-M., Rambal, S., Miglietta, F., Peressotti, A., Pecchiari, M., Tirone, G., and Valentini, R.: Severe drought effects on ecosystem $\mathrm{CO}_{2}$ and $\mathrm{H}_{2} \mathrm{O}$ fluxes at three Mediterranean evergreen sites: revision of current hypotheses?, Glob. Change Biol., 8, 999-1017, 2002 b. 
Reichstein, M., Rey, A., Freibauer, A., Tenhunen, J., Valentini, R., Banza, J., Casals, P., Cheng, Y., Grünzweig, J. M., Irvine, J., Joffre, R., Law, B. E., Loustau, D., Miglietta, F., Oechel, W., Ourcival, J.-M., Pereira, J. S., Ponti, F., Qi, Y., Rambal, S., Rayment, M., Romanya, J., Rossi, F., Tedeschi, V., Tirone, G., Xu, M., and Yakir, D.: Modeling temporal and large-scale spatial variability of soil respiration from soil water availability, temperature and vegetation productivity indices, Global Biogeochem. Cy., 17, 1104, doi:10.1029/2003GB002035, 2003.

Reynolds, J. F.: Desertification, in: Encyclopedia of Biodiversity, edited by: Levin, S. A., vol. 2, Academic Press, San Diego, 6178, 2001.

Riveros-Iregui, D. A., Emanuel, R. E., Muth, D. J., McGlynn, B. L., Epstein, H. E., Welsch, D. L., Pacific, V. J., and Wraith, J. M.: Diurnal hysteresis between soil $\mathrm{CO}_{2}$ and soil temperature is controlled by soil water content, Geophys. Res. Lett., 34, L17404, doi:10.1029/2007GL030938, 2007.

Schimel, D. S.: Terrestrial ecosystems and the carbon cycle, Glob. Change Biol., 1, 77-91, 1995.

Schimel, D. S., House, J. I., Hibbard, K. A., Bousquet, P., Ciais, P., Peylin, P., Braswell, B. H., Apps, M. J., Baker, D., Bondeau, A., Canadell, J., Churkina, G., Cramer, W., Denning, A. S., Field, C. B., Friedlingstein, P., Goodale, C., Heimann, M., Houghton, R. A., Melillo, J. M., Moore, B., Murdiyarso, D., Noble, I., Pacala, S. W., Prentice, I. C., Raupach, M. R., Rayner, P. J., Scholes, R. J., Steffen, W. L., and Wirth, C.: Recent patterns and mechanisms of carbon exchange by terrestrial ecosystems, Nature, 414, 169$172,2001$.

Skopp, J., Jawson, M. D., and Doran, J. W.: Steady-state aerobic microbial activity as a function of soil water content, Soil Sci. Soc. Am. J., 54, 1619-1625, 1990.

Sotta, E. D., Veldkamp, E., Schwendenmann, L., Guimarães, B. R., Paixão, R. K., Ruivo, M. L. P., Costa, A. C. L., and Meir, P.: Effects of an induced drought on soil carbon dioxide $\left(\mathrm{CO}_{2}\right)$ efflux and soil $\mathrm{CO}_{2}$ production in an Eastern Amazonian rainforest, Brazil, Glob. Change Biol, 13, 2218-2229, 2007.

Subke, J.-A., Reichstein, M., and Tenhunen, J. D.: Explaining temporal variation in soil $\mathrm{CO}_{2}$ efflux in a mature spruce forest in Southern Germany, Soil Biol. Biochem., 35, 1467-1483, 2003.

Tang, J., Baldocchi, D. D., and Xu, L.: Tree photosynthesis modulates soil respiration on a diurnal time scale, Glob. Change Biol., 11, 1298-1304, 2005.
Van't Hoff, J. H.: Lectures on theoretical and physical chemistry. In: Chemical Dynamics: Part 1, edited by: Lehfeldt, R. A., 224-229, Edward Arnold, London, UK, 1898.

Vargas, R. and Allen, M. F.: Environmental controls and the influence of vegetation type, fine roots and rhizomorphs on diel and seasonal variation in soil respiration, New Phytol., 179, 460-471, 2008.

Wang, G., Ma, H., Qian, J., and Chang, J.: Impact of land use changes on soil carbon, nitrogen and phosphorus and water pollution in an arid region of northwest China, Soil Use. Manage., 20, 32-39, 2004.

Wetherald, R. T. and Manabe, S.: Simulation of hydrologic changes associated with global warming, J. Geophys. Res., 107, 1-15, 2002.

Winkler, J. P., Cherry, R. S., and Schlesinger,W. H.: The $Q_{10}$ relationship of microbial respiration in a temperate forest soil, Soil Biol. Biochem., 28, 1067-1072, 1996.

$\mathrm{Xu}, \mathrm{M}$. and Qi, Y.: Soil-surface $\mathrm{CO}_{2}$ efflux and its spatial and temporal variations in a young ponderosa pine plantation in northern California, Glob. Change Biol., 7, 667-677, 2001.

Yu, X., Zha, T., Pang, Z., Wu, B., Wang, X., Chen, G., Li, C., Cao, J., Jia, G., Li, X., and Wu, H.: Response of soil respiration to soil temperature and moisture in a 50-year-old oriental arborvitae plantation in China, Plos One, 6, e28397, doi:10.1371/journal.pone.0028397, 2011.

Yuste, J. C., Janssens, I. A., Carrara, A., Meiresonne, L., and Ceulemans, R.: Interactive effects of temperature and precipitation on soil respiration in a temperate maritime pine forest, Tree Physiol., 23, 1263-1270, 2003.

Zhang, L., Chen, Y., Zhao, R., and Li, W.: Significance of temperature and soil water content on soil respiration in three desert ecosystems in Northwest China, J. Arid Environ., 74, 12001211, 2010.

Zheng, Z., Yu, G., Fu, Y., Wang, Y., Sun, X., and Wang, Y.: Temperature sensitivity of soil respiration is affected by prevailing climatic conditions and soil organic carbon content: a trans-China based case study, Soil Biol. Biochem., 41, 1531-1540, 2009.

Zhou, T., Shi, P., Hui, D., and Luo, Y.: Global pattern of temperature sensitivity of soil heterotrophic respiration $\left(Q_{10}\right)$ and its implications for carbon-climate feedback, J. Geophys. Res., 114, G02016, doi:10.1029/2008JG000850, 2009. 